\title{
Germination in Seed Species Ingested by Opossums: Implications for Seed Dispersal and Forest Conservation
}

\author{
Nilton Carlos Cáceres ${ }^{1,2} *$ and Emygdio Leite de Araújo Monteiro-Filho ${ }^{1,3}$ \\ ${ }^{1}$ CPGZool; Departamento de Zoologia; Universidade Federal do Paraná; nc_caceres@hotmail.com; Curitiba - PR \\ - Brasil. ${ }^{2}$ Departamento de Biologia; Universidade Federal de Santa Maria; Santa Maria - RS - Brasil. ${ }^{3}$ Instituto de \\ Pesquisas Cananéia; Rua João Salim; Lote 26; Quadra Y; Parque Xangrilá; 13.098-106; kamonteiro@uol.com.br; \\ Campinas - SP - Brasil
}

\begin{abstract}
Seed germination in plant species consumed by opossums, genus Didelphis, was investigated in southern Brazil, in order to improve knowledge of the strategies of zoochorous plants in the Neotropics. Seeds were obtained from opossum feces. Thirteen of the most frequent species in the diet of local opossums were tested for germination rates and germination responses under different qualities (red/far red ratio) and different intensities of light. Most seeds from feces germinated similarly to the control groups, except for seeds of Rubus rosifolius, which appeared to depend on gut passage. Other experiments revealed that most seeds in the opossums' diet were of pioneer species, with most germination occurring during favorable humid conditions in the rainy season. A few species showed negative photoblastism, or no dormancy pattern. Small mammals are suggested as possible tools for area recuperation programs, through seed dispersal of many pioneer and some shade-tolerant plants, under suitable management.
\end{abstract}

Key words: Seed germination, light quality, dormancy, marsupials

\section{INTRODUCTION}

Angiosperm seeds generally show some type of dormancy, as a result of adaptation to environment in space and time. In nature, some seeds are adapted to germinate under light, others in its absence, by scarification, in decreasing or optimal temperatures, or through other strategies (GómesPompa and Vázquez-Yanes, 1981; Metivier, 1985; Ferraz-Grande and Takaki, 2001). Many seeds and sprouts of Neotropical plant species germinate in the beginning of the wet season to assure full development during a period of surplus water (Garwood, 1983; Morellato et al., 2000). In many tropical species, light is the main cue to break dormancy and to begin development, especially in pioneer and secondary plants such as species of Piper and Cecropia (Gómes-Pompa and VázquezYanes, 1981; Vázquez-Yanes and OrozcoSegovia, 1986; Orozco-Segovia et al., 1993; Vázquez-Yanes et al., 1996). The seed scarification that occurs in the digestive tract of animals is also important because, in addition to usually promoting germination (which is speciesdependent), it is also related to transport of seeds away from the parent plant (Janzen, 1980; Reis and Guillaumet, 1983; Bodmer, 1991; Passos, 1997). However, under temperate conditions, seeds tend to show different germination strategies (Gómes-Pompa and Vázquez-Yanes, 1981), such

\footnotetext{
${ }^{*}$ Author for correspondence
} 
as the need to undergo the low temperatures of winter in order to germinate (Metivier, 1985).

Plants must be dispersed to suitable germination sites (Jordano, 1992; Schupp 1993). Among dispersal syndromes, those mediated by the wind and animals are prominent (Howe and Smallwood, 1982; Morellato et al., 2000). The most common animal syndromes are ornithochory by birds and chiropterochory by bats (Janzen, 1980; van der Pijl, 1982; Gorchov et al., 1993). There is no recognizable dispersal syndrome allocated to small, nocturnal, nonvolant mammals.

Didelphid marsupials are small mammals that are common in dense, cloud, and mixed Neotropical forests (Emmons and Feer, 1997). Didelphids seem to perform an important, but not well quantified, role in seed dispersal in the neotropics (Charles-Dominique et al., 1981; Atramentowicz 1988; Medellín, 1994; Cáceres et al., 1999; Carvalho et al., 1999). Nonetheless, little is known of their role in forest regeneration and maintenance. The role of Neotropical vertebrate frugivores in seed dispersal is usually studied in birds, bats and large mammals (e.g., Gorchov et al., 1993; Galleti and Aleixo, 1998; Da Silva and Tabarelli, 2000). In this context, the present study examined the germination strategies of seed species whose fruits are often consumed by marsupials of the genus Didelphis, in order to relate these strategies to seed dispersal and forest management in disturbed areas.

\section{METHODS}

\section{Study area}

The study was carried out in a small forest fragment (5 ha) in Curitiba, state of Paraná $\left(25^{\circ}\right.$ $25^{\prime} \mathrm{S}$ and $49^{\circ} 18^{\prime} \mathrm{W}, 940 \mathrm{~m}$ a.s.l.). The fragment is located in a suburban area belonging to the Companhia Paranaense de Energia (COPEL), and is surrounded by residences, buildings, roads and barren lands. The area was covered by disturbed and secondary mixed ombrophyll forest, with an unpolluted creek in its interior. Some of the main tree species were Araucaria angustifolia (Bertol.) Kuntze (Araucariaceae), Podocarpus lambertii Klotzsch (Podocarpaceae), Jacaranda puberula Cham. (Bignoniaceae), Ocotea puberula Nees (Lauraceae), Casearia sylvestris $\mathrm{Sw}$. (Flacourtiacaeae), Zanthoxylum rhoifolium Lam. (Rutaceae), Solanum sanctaecatharinae and Solanum granuloso-leprosum (Solanaceae). Common shrubs were Piper gaudichaudianum (Piperaceae) and Rudgea jasminioides (Cham.) Müell. Arg. (Rubiaceae); the lianas Passiflora actinia Hooker (Passifloraceae) and Pithecoctenium crucigerum (L.) A.H. Gentry (Bignoniaceae) were also common. The mean annual temperature of the region is $17^{\circ} \mathrm{C}$. The annual rainfall of 1600 to $2000 \mathrm{~mm}$ is concentrated mainly in the warm season, September through March (Maack, 1981) (Fig. 1).

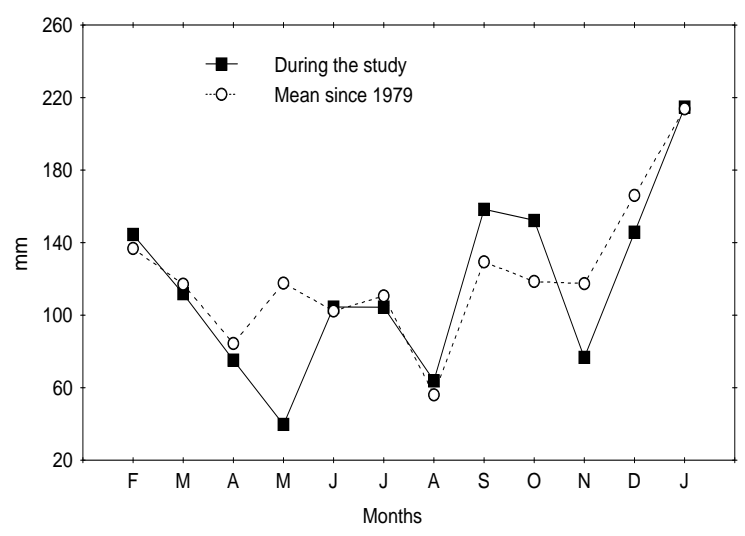

Figure 1 - Monthly variation of rainfall (in $\mathrm{mm}$ ) in the study area during the years when opossums were captured (1995-96: squares), and monthly means from 1979 to 1994 (circles)

\section{Trapping for feces and seeds}

Animals used for this study were Didelphis albiventris Lund, 1840 and D. aurita WiedNeuwied, 1826 (Mammalia, Didelphidae), weighing usually 1 to $2 \mathrm{~kg}$. To capture them, 30 live traps $(\sim 40 \times 20 \times 20 \mathrm{~cm})$ were set in an irregular grid pattern $(\sim 40 \mathrm{~m}$ apart from each other) in the study area. Traps were set one night per week, for 
one year, from February 1995 through January 1996. Bait was a mixture of banana, peanut butter and cod liver oil. Additional data on D. albiventris feces and fruits were obtained in another area $8 \mathrm{~km}$ distant, with the same forest coverage and disturbance level.

Feces obtained from captured animals were searched for seeds, which were washed on a 1-mm mesh screen and analyzed under a stereomicroscope.

\section{Effects of gut passage on seeds}

Seeds found in feces were tested for the germination in closed Petri dishes containing moist paper. Results from individual or groups of seeds affected by fungi or excessively dried during the experiment were excluded from the analyses. To test the effect of gut passage on seeds, germination tests were also carried out with seeds of ripe fruits collected directly from parent plants (control treatment) in the study area, from 1997 through 1999. All seeds, from both treatments of feces and fruits, were placed for germination in a natural environment under shrubs, resembling a gap in the first successional stage of regeneration (capoeira).

\section{Germination under different light intensities and qualities}

Two groups of seeds (all from fruits) were treated separately under different light intensities to simulate environmental conditions, and were placed in a greenhouse. The first group was placed in a shaded site, out of direct sunlight, averaging 700 lux. The second group was placed in a culture chamber covered with $2 \mathrm{~mm}$ mesh, which decreased the sunlight by $\sim 70 \%$ (10,000 lux). Daily variations of temperature and relative humidity were recorded in two periods of the year (June-July 1999 and January-February 2000), for 10-day periods, in order to monitor seasonal effects. These ranged from $16.4^{\circ}$ to $21.3^{\circ} \mathrm{C}$ and 84.1 to $86.7 \%$ on average for the chamber at light condition (respectively).

To determine what seed species were affected differentially by light quality for germination, the $\mathrm{red} /$ far red ratio test was used in the laboratory under ambient temperature. The red wavelength $(660 \mathrm{~nm})$ is more abundant in white light, as it reaches large forest gaps; whereas the far red wavelength $(730 \mathrm{~nm})$ is more abundant in the forest interior. The red wavelength is the cue for activation of germination in positive photoblastic seeds (Vázquez-Yanes and Orozco-Segovia, 1986).

Species with low germination frequencies were tested for negative photoblastic property by placing groups of seeds buried $1 \mathrm{~cm}$ deep in glass containers. Seeds were placed at the soil surface in adjacent glasses as a control.

The maximum germination time (estimated time of dormancy) was recorded for those groups with more than 20 seeds germinated (for all treatments). Even if most seeds germinated in an experimental group, or even if none germinated in a short period of time, their seeds were monitored for 1 to 2 years.

\section{Statistic analyses}

The different comparisons among treatments were tested by using the proportion test $\left(\mathrm{p}_{1}\right.$ and $\left.\mathrm{p}_{2}\right)$ based on sample sizes $(\mathrm{N})$ and on the value of Student's $t$ obtained (Statistica, 1993).

\section{RESULTS}

\section{Seed germination}

In total, 28 seed species were found in the feces of opossums (see details in Cáceres and MonteiroFilho, 2001; and Cáceres, 2002). Only 50\% of the species were treated here (Table 1), because a part of the fruit species was not possible to collect in the field. All seeds were small in size $(<15$ $\mathrm{mm}$ ), and showed moderate to high germination frequencies.

Most of the seeds that passed through opossum guts did not show significant differences from the control groups. However, Rubus rosifolius germinated at significantly higher frequencies than the controls $(\mathrm{P}<0.01$; Table 1$)$. Because they germinated fully under both shaded and lighted conditions, Piper gaudichaudianum and Leandra australis differed from the rest of the species, which germinated significantly only under light and at higher levels. Seeds of Rubus rosifolius and Passiflora actinia did not germinate well in either light or shade (Table 1).

As a result of the red/far red ratio test, $38 \%$ of all species responded to the test, showing positive photoblastism. $P$. gaudichaudianum and $L$. australis showed no response to these treatments, germinating in both cases (Table 1). Rubus rosifolius, Cyphomandra corymbiflora and Solanum granuloso-leprosum did not germinate in any treatment, under different light qualities 
(Table 1). Only Passiflora actinia was negatively photoblastic, with low levels of germination in light, but showed a $60 \%$ germination rate $\mathrm{N}=20$ when their seeds were buried (contrasting with no germination at the soil surface $\mathrm{N}=20$ ).

\section{Dormancy}

Most seed species consumed by marsupials showed dormancy (62\%), whereas only $31 \%$ showed rapid germination (less than two months). The mean time of dormancy prior to germination varied from six to 12 months, depending on the species. $P$. gaudichaudianum always germinated rapidly (in a few weeks), independent of treatment, never requiring more than two months to germinate (Table 1).

Most species germinated after the winter solstice, coinciding with the onset of the rainy season or germinated quickly, still in the same rainy season, when they were dispersed (Fig. 2).

\section{DISCUSSION}

At first analysis, didelphid marsupials feed mainly on fruits with small, pioneer seeds, but there were seeds with other strategies than germinating under full light, such as the mechanisms of germinating rapidly after dispersal, or even negative photoblastism. General ecological studies of seed dispersal by mammals are carried out only, and rather exclusively, by using germination under light conditions (e.g., Motta-Júnior et al., 1994; Passos, 1997; Cáceres and MonteiroFilho, 2000; Quadros and Monteiro-Filho, 2000). However, the low levels of germination seen in those experiments may be due to other germination strategies, rather than under full light (e.g., negative photoblastism).

In general, seeds in the opossums' diet showed dormancy, at least those that were ingested and usually appeared in their feces.

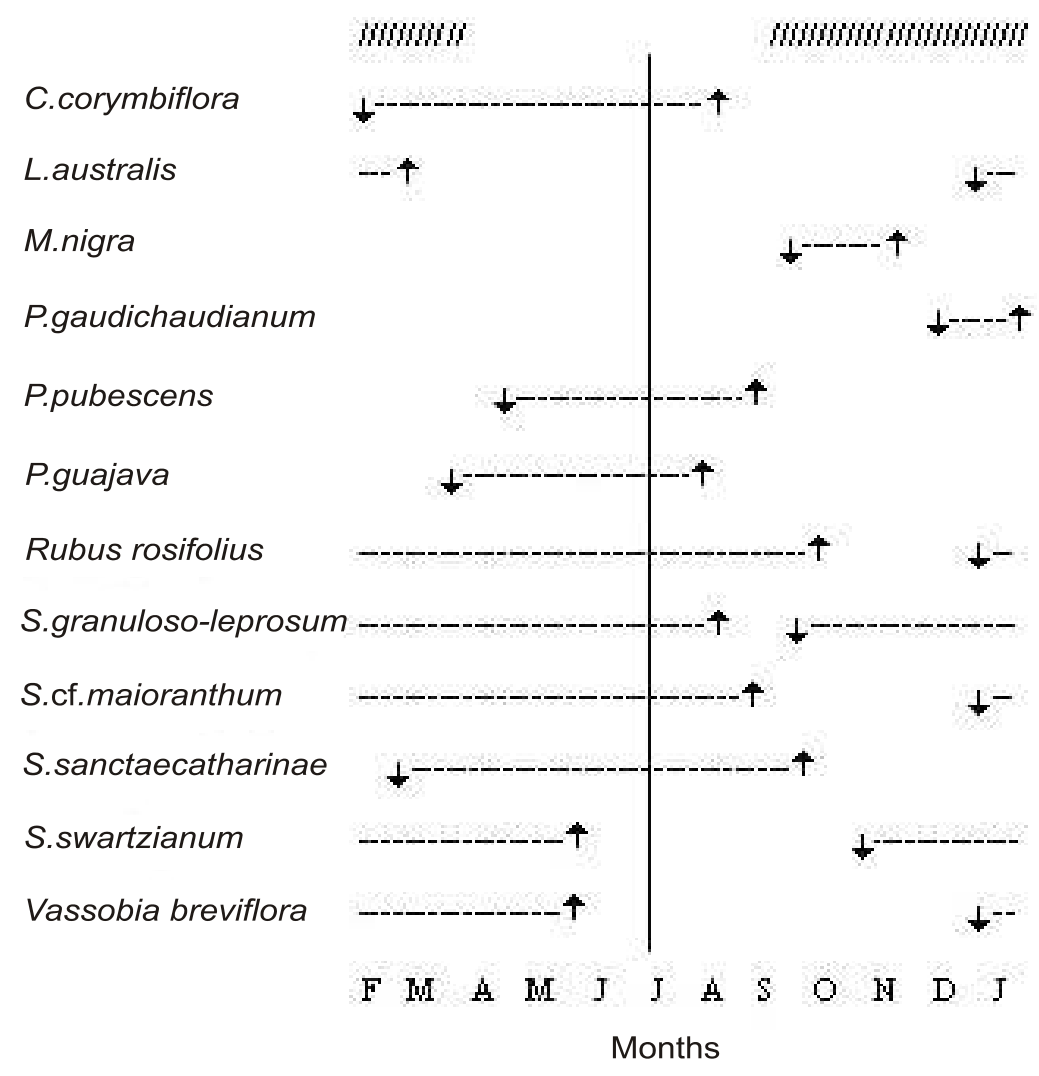

Figure 2 - Main period of dormancy and germination of seeds in the diet of Didelphis in mixed ombrophyll forest patches in southern Brazil. Genera are Cyphomandra, Leandra, Morus, Piper, Physalis, Psidium, Rubus, Solanum and Vassobia, respectively. Bars above indicate the warmer and wetter season. Vertical line indicates the winter solstice. $\downarrow$ indicates the mean time of seed dispersal; horizontal lines indicate mean duration of dormancy; $\uparrow$ indicates the mean time of seed germination 
An unknown number of fruits with larger seeds (presumably over $1.5 \mathrm{~cm}$ in diameter) is usually rejected by Didelphis near parent plants (e.g., Charles-Dominique et al., 1981; Atramentowicz, 1988). Because the study area was a small, disturbed forest fragment, this last fact should have favored the appearance of a higher proportion of small, pioneer seeds in the opossum feces (Cáceres and Monteiro-Filho, 2001). However, Didelphis spp. appear to ingest more shadetolerant seed species in non-disturbed forest (Vieira and Izar, 1999). Disturbed or secondary forests usually show a higher proportion of small pioneer seeds, that is, plant species that germinate under full light (Gómes-Pompa and Vázquez-
Yanes, 1981; Garwood 1983; Gandolfi et al., 1995). In southeastern Brazil, species of Leandra (Melastomataceae) and Solanum (Solanaceae), taxa consumed by opossums, compose a large part of the forest seed bank (Baider et al., 1999; Grombone-Guaratini et al., 2004).

This places these marsupials as potential integrants of the respective seed dispersal communities (see also Uhl et al., 1988). Furthermore, Cecropia, a genus also consumed by opossums (Medellín, 1994; Grelle and Garcia, 1999) and which exhibits dormancy, is also abundant in Neotropical forest seed banks (Vázquez-Yanes et al., 1996; Grombone-Guaratini et al., 2004).

Table 1 - Germination frequencies (in \%) of seeds from fruits and feces; effects of light intensity (\%) and of red/far red ratio in seed germination and duration of dormancy in seeds dispersed by two opossum species (Didelphis albiventris and $D$. aurita), in disturbed mixed ombrophyll forest in southern Brazil.

\begin{tabular}{|c|c|c|c|c|c|c|c|c|}
\hline \multirow[t]{2}{*}{ Fruit species } & \multicolumn{3}{|c|}{ D. albiventris } & \multicolumn{3}{|c|}{ D. aurita } & \multicolumn{2}{|c|}{ Control } \\
\hline & Feces & $\mathbf{N}$ & & Feces & $\mathbf{N}$ & & Fruits & $\mathbf{N}$ \\
\hline Cyphomandra corymbiflora Sendtn. & 98 & $(41)$ & & 60 & $(65)$ & & 82 & $(50)$ \\
\hline Leandra australis (Cham.) Cogn. & 100 & (13) & & & & & 87 & $(30)$ \\
\hline Morus nigra $\mathrm{L}$. & 65 & (71) & & 75 & $(8)$ & & 68 & $(25)$ \\
\hline Passiflora actinia Hooker & 15 & $(41)$ & & 13 & (71) & & 0 & $(20)$ \\
\hline Physalis pubescens L. & 87 & $(100)$ & & 86 & $(38)$ & & 79 & $(110)$ \\
\hline Piper gaudichaudianum Kunth & & & & 94 & $(50)$ & & 94 & $(65)$ \\
\hline Psidium guajava $\mathrm{L}$ & 82 & (11) & & 71 & (24) & & 92 & $(25)$ \\
\hline Rubus rosifolius Stokes & 67 & $(55)$ & $*$ & 68 & (99) & $*$ & 13 & (39) \\
\hline Solanum granuloso-soleprosum Dun. & & & & 57 & $(113)$ & & 72 & $(25)$ \\
\hline S. cf. maioranthum L.B.Sm. and Downs & 71 & $(07)$ & & & & & & \\
\hline S. sanctaecatharinae Dun. & 40 & (90) & $*$ & 57 & $(56)$ & $*$ & 88 & $(25)$ \\
\hline S. swartzianum Roem. and Schult. & & & & 52 & $(31)$ & & 25 & $(20)$ \\
\hline Vassobia breviflora (Sendtn.) Munz. & 81 & $(26)$ & & 65 & $(66)$ & & 87 & $(30)$ \\
\hline \multirow{2}{*}{ Fruit species } & \multicolumn{4}{|c|}{ "Light and shadow effects } & \multicolumn{2}{|c|}{ Proportion } & \multirow{2}{*}{\multicolumn{2}{|c|}{$\begin{array}{l}\text { Dormancy } \\
\text { (in months) }\end{array}$}} \\
\hline & Light & $\mathbf{N}$ & \multicolumn{2}{|c|}{ Shadow N } & \multicolumn{2}{|c|}{ Red/Far red ${ }^{c}$} & & \\
\hline Cyphomandra corymbiflora Sendtn. & 88 & $(65) *$ & 13 & $(30)$ & - & $(55)$ & \multicolumn{2}{|c|}{$\frac{(\text { (n months) }}{7.4 \text { b }}$} \\
\hline Leandra australis (Cham.) Cogn. & 46 & $(90)$ & 32 & (60) & $28: 31^{\mathrm{F}}$ & (90) & 2.8 & \\
\hline Morus nigra L. & 24 & $(25)$ & 4 & (25) & $5: 0^{\mathrm{R}^{*}}$ & $(25)$ & 1.6 & $\mathrm{~b}$ \\
\hline Passiflora actinia Hooker & 0 & (20) & 0 & (20) & - & $(40)$ & 12.0 & a \\
\hline Physalis pubescens L. & 66 & $(35) *$ & 13 & (70) & $45: 1^{\mathrm{R}^{* *}}$ & $(65)$ & 7.2 & $\mathrm{~b}$ \\
\hline Piper gaudichaudianum Kunth & 80 & $(35)$ & 85 & (60) & $51: 54^{\mathrm{F}}$ & $(65)$ & 0.9 & \\
\hline Psidium guajava $\mathrm{L}$ & 91 & $(22) *$ & 27 & (22) & $38: 1^{\mathrm{R}^{* *}}$ & (42) & 1.9 & \\
\hline Rubus rosifolius Stokes & 6 & $(35)$ & 6 & (33) & - & $(40)$ & 9.0 & $\mathrm{~b}$ \\
\hline Solanum granuloso-soleprosum Dun. & 67 & $(30) *$ & 0 & (30) & - & $(55)$ & 11.6 & $\mathrm{~b}$ \\
\hline S. cf. maioranthum L.B.Sm. and Downs & 100 & $(40)$ & & & $10: 0^{\mathrm{R}^{* *}}$ & $(25)$ & 1.1 & \\
\hline S. sanctaecatharinae Dun. & 84 & $(25) *$ & 0 & (25) & $14: 0^{\mathrm{R}^{* *}}$ & $(25)$ & 6.4 & $\mathrm{~b}$ \\
\hline S. swartzianum Roem. and Schult. & & & & & & & 6.2 & a \\
\hline Vassobia breviflora (Sendtn.) Munz. & 71 & $(35) *$ & 0 & $(25)$ & & & 6.4 & $\mathrm{~b}$ \\
\hline
\end{tabular}


The fact that $P$. gaudichaudianum germinated under all treatments, including red/far red ratios, indicates the absence of dormancy in this species, similar to the strategy adopted by Ficus in the northern Neotropics (Vázquez-Yanes et al., 1996). However, other species of Piper exhibit different strategies, such as dormancy for several years in unfavorable situations (Orozco-Segovia et al., 1993; Vázquez-Yanes and Orozco-Segovia, 1993). Thus, $P$. gaudichaudianum must be dispersed rapidly after fruiting and during favorable times (wet season) for its successful establishment (e.g., favorable temperatures and ample water; Socolowski and Takaki, 2004), to increase the chances of seedling survival (e.g., Foster, 1982; Garwood, 1983). Accordingly, seed germination is important during the early rainy season in the Atlantic rainforest, even in a less seasonal biome (Morellato et al., 2000) such as a mixed forest like the study area. Furthermore, habitat requirements for the development of $P$. gaudichaudianum are most probably the forest interior and small forest gaps (personal observation), since its seeds do not germinate reasonably under full light (Cáceres and Monteiro-Filho, 2000).

Shade-tolerant species occurred at low frequencies in the diet of opossums, at least in this small fragment. This could be partly due to the invasion of pioneer plants from the matrix (open area) to the forest interior, or from the edge to the forest interior, as seen elsewhere (Gandolfi et al., 1995; Tabanez et al., 1997; Da Silva and Tabarelli, 2000). This historical invasion must have changed the proportions of shade and pioneer plants in the fragment. This change can be inferred from the higher floral richness of pioneer plants recorded in a similar, but larger, forest fragment located only 1 $\mathrm{km}$ from the study area (C. Kosera, V.A.O. Dittrich and S.M. Silva, unpublished data). Nonetheless, Didelphis spp. must contribute to dispersal of seeds from outside fragments to the interior, and vice-versa (e.g., Cáceres and Monteiro-Filho, 2001), because of their high rates of migration and dispersal among fragmented landscapes (Pires et al., 2002).

The increase of germination capacity after opossum gut passage, as indicated for Rubus rosifolius, was previously reported for other wild mammals such as bats (Reis and Guillaumet, 1983) and primates (Figueiredo, 1993; Passos, 1997). In these cases, only a small number of seed species, in regard to the complete spectrum of species, exhibited this strategy. This increase in the probability of seed germination is thought to make certain plants more dependent on their dispersal agents for reproductive success.

Most opossum-dispersed seeds appear to be transported only endozoochorically and chemical scarification does not usually affect their viability, neither increasing nor decreasing germination rates. Such seed types (small-sized ones) are thought to accept a wide array of dispersal agents (e.g., Bodmer, 1991; Jordano 1992). Furthermore, in Didelphis, seeds pass relatively rapid through the gut, within $4 \mathrm{~h}$ to 1 day, depending on the plant species (N.C. Cáceres, unpublished data). This is not harmful to seeds, as pointed out by Jordano (1992) in studies of passage times for seeds in vertebrate guts.

According to the main germination time of most species seen here (averaging from the end of the winter solstice to the beginning of the period of heavy rainfall), it could be inferred that the dormancy break was related to, and initiated by increasing humidity in the seed coat and embryo after consecutive rains and/or increasing day length (Garwood, 1983; Metivier, 1985). The importance of humidity, or water surplus to increase the probability of germination when a seed is dormant (Vázquez-Yanes and OrozcoSegovia, 1993; Socolowski and Takaki, 2004) corroborates this.

Examination of the role of didelphid marsupials in the dynamics of seed germination and dispersal in fragmented and undisturbed areas has provided interesting scenarios and their role needs to be better understood. In light of the data presented and discussed here (germination probabilities, differential germination processes, dormancy and rapid germination, movement pattern of opossums in disturbed areas, etc.), opossums could be also considered as management tools for forest regeneration.

\section{ACKNOWLEDGEMENTS}

The authors thank A. Domingues for help in the germination experiments, S.M. Silva for plant identifications, J.C. Voltolini for help in statistical treatments, J.W. Reid for English revision, and J.B.R. Aquino and M.E.V. Ferreira for help in the 
field experiments. Special thanks to the anonymous referees whose contributions have improved the paper. The Curso de Pós-Graduação em Zoologia (UFPR - Federal University of Paraná, Brazil) provided logistical support, and the Brazilian Council for Graduate Personal Improvement (CAPES) provided a doctoral fellowship to NCC.

\section{RESUMO}

Com o objetivo de fornecer conhecimento adicional acerca das estratégias de germinação adotadas por espécies de plantas zoocóricas da Região Neotropical, foram examinadas a dormência e germinação de sementes consumidas por marsupiais do gênero Didelphis. As sementes foram obtidas de fezes dos animais capturados em armadilhas, sendo então analisadas. As espécies mais freqüentes na dieta dos gambás $(\mathrm{N}=13)$ foram testadas quanto a sua viabilidade e possíveis mecanismos de quebra de dormência pela luz (condições de luz vs. sombra vs. escuro; e sob $\underline{\text { red/far }}$ red ratio). A maioria das espécies provenientes das fezes germinou similarmente ao grupo controle, exceto por Rubus rosifolius que parece depender da passagem pelo trato digestivo para a germinação. Outros experimentos mostraram que as espécies de plantas eram principalmente pioneiras, com quebra de dormência principalmente durante a estação mais úmida e favorável ao desenvolvimento. Uma menor proporção de espécies apresentou fotoblastismo negativo ou nenhum padrão de dormência. Os resultados mostram que estes pequenos mamíferos podem ser utilizados em programas de recuperação de áreas degradadas, com enfoque na dispersão de sementes de plantas pioneiras.

\section{REFERENCES}

Atramentowicz, M. (1988), La frugivorie opportuniste de trois marsupiaux didelphidés de Guyane. Revue d'Ecologie Terre et Vie, 43, 47-57.

Baider, C.; Tabarelli, M. and Mantovani, W. (1999), O banco de sementes de um trecho de Floresta Atlântica Montana (São Paulo, Brasil). Revista Brasileira de Biologia, 59, 319-328.
Bodmer, R. E. (1991), Strategies of seed dispersal and seed predation in Amazonian ungulates. Biotropica, 23, 255-261.

Cáceres, N. C.; Dittrich, V. A. O. and Monteiro-Filho, E. L. A. (1999), Fruit consumption, distance of seed dispersal and germination of Solanaceous plants ingested by the common opossum (Didelphis aurita) in southern Brazil. Revue d'Ecologie Terre et Vie, 54, 225-234.

Cáceres, N. C. and Monteiro-Filho, E. L. A. (2000), The common opossum, Didelphis aurita, as a seed disperser of several plants in southern Brazil. Ciência e Cultura, 52, 41-44.

Cáceres, N. C. and Monteiro-Filho, E. L. A. (2001), Food habits, home range and activity of Didelphis aurita (Mammalia, Marsupialia) in a forest fragment of southern Brazil. Studies on Neotropical Fauna and Environmental, 36, 85-92.

Carvalho, F. M. V.; Pinheiro, P. S.; Fernandez, F. A. S. and Nessimian, J. L. (1999), Diet of small mammals in Atlantic Forest fragments in southeastern Brazil. Revista Brasileira de Zoociências, 1, 91-101.

Charles-Dominique, P.; Atramentowicz, M.; CharlesDominique, M.; Gerard, H.; Hladik, A.; Hladik, C. M. and Prévost, M. F. (1981), Les mammiferes frugivores arboricoles nocturnes d'une foret guyanaise: inter-relations plantes-animaux. Revue d'Ecologie Terre et Vie, 35, 340-435.

Da Silva, J. M. C. and Tabarelli, M. (2000), Tree species impoverishment and the future flora of the Atlantic forest of northeast Brazil. Nature, 404, 7274.

Emmons, L. H. and Feer, F. (1997), Neotropical rainforest mammals: a field guide. University of Chicago Press, Chicago.

Ferraz-Grande, F. G. A. and Takaki, M. (2001), Temperature dependent seed germination of Dalbergia nigra Allem (Leguminosae). Brazilian Archives of Biology and Technology, 44, 401-404.

Figueiredo, R. A. (1993), Ingestion of Ficus enormis seeds by howler monkeys (Alouatta fusca) in Brazil: effects on seed germination. Journal of Tropical Ecology, 9, 541-543.

Foster, R. B. (1982), The seasonal rhythms in fruitfall on Barro Colorado Island. In: The ecology of a tropical forest, ed. E. G. Leigh-Jr. et al. Smithsonian Institution Press, Washington, pp. 151-172.

Galleti, M. and Aleixo, A. (1998), Effects of palm heart harvesting on avian frugivores in the Atlantic rain forest of Brazil. Journal of Applied Ecology, 35, 286293.

Gandolfi, S.; Leitão-Filho, H. F. and Bezerra, C. L. F. (1995), Levantamento florístico e caráter sucessional das espécies arbustivo-arbóreas de uma floresta mesófila semidecídua no município de Guarulhos, SP. Revista Brasileira de Biologia, 55, 753-767. 
Garwood, N. C., 1983, Seed germination in a seasonal tropical forest in Panama: a community study. Ecological Monographs, 53, 159-181.

Gómes-Pompa, A. and Vázquez-Yanes, C. (1981), Successional studies of a rain forest in Mexico. In: Forest succession: concepts and application, eds. D. C. West, H. H. Shugart and D.B. Botkin. SpringerVerlag, New York, pp. 246-266.

Gorchov, D. L.; Cornejo, F.; Ascorra, C. and Jaramillo, M. (1993), The role of seed dispersal in the natural regeneration of rain forest after strip-cutting in the Peruvian Amazon, In: Frugivory and seed dispersal: ecological and evolutionary aspects. Eds. T. H. Fleming and A. Estrada. Kluwer, Belgium, pp. 339349.

Grelle, C. E. V. and Garcia, Q. S. (1999), Potential dispersal of Cecropia hololeuca by the common opossum (Didelphis aurita) in Atlantic forest, southeastern Brazil. Revue.d' Ecologie Terre et Vie, 54, 327-332.

Gromobone-Guaratine, M.T., Leitão-Filho, H.F. and Kageyama, P.Y. (2004). The seed bank of a gallery forest in southeastern Brazil. Brazilian Archives of Biology and Technology, 47, 793-797.

Howe, H. F. and Smallwood, J. (1982), Ecology of seed dispersal. Annual Review of Ecology and Systematics, 13, 201-228.

Janzen, D. H. (1980), Ecologia vegetal nos trópicos. Editora Pedagógica e Universitária, São Paulo.

Jordano, P. (1992), Fruits and frugivory. In: The ecology of regeneration in plant communities, ed. M. Fenner. CAB International, Wallingford, pp. 105-156.

Maack, R. (1981), Geografia física do Estado do Paraná. J. Olympio, Rio de Janeiro.

Medellín, R A. (1994), Seed dispersal of Cecropia obtusifolia by two species of opossums in the Selva Lacandona, Chiapas, Mexico. Biotropica, 26, 400407.

Metivier, J. R. (1985), Dormência e germinação. In: Fisiologia vegetal 2, ed. M. G. Ferri. Editora Pedagógica e Universitária, São Paulo, pp. 343-392.

Morellato, L. P. C.; Talora, D. C.; Takahasi, A.; Bencke, C. C.; Romera, E. C. and Zipparro, V. B. (2000), Phenology of Atlantic rain forest trees: a comparative study. Biotropica, 32, 811-823.

Motta-Júnior, J. C., Lombardi, J. A., Talamoni, S. A., 1994, Notes on crab-eating fox (Dusicyon thous) seed dispersal and food habits in southeastern Brazil. Mammalia, 58, 156-159.

Orozco-Segovia, A.; Sanchez-Coronado, M. E. and Vázquez-Yanes, C. (1993), Light environment and phytochrome-controlled germination in Piper auritum. Functional Ecology, 7, 585-590.

Passos, F. C. (1997), Seed dispersal by black lion tamarin, Leontopithecus chrysopygus (Primates, Callitrichidae), in southeastern Brazil. Mammalia, 61, 109-111.
Pires, A. S.; Lira, P. K.; Fernandez, F. A. S.; Schittini, G. M. and Oliveira, L. C. (2002), Frequency of movements of small mammals among Atlantic Coastal Forest fragments in Brazil. Biological Conservation, 108, 229-237.

Quadros, J. and Monteiro-Filho, E. L. A. (2000), Fruit occurrence in the diet of the neotropical otter Lontra longicaudis (Ofers, 1818) in an Atlantic Forest area, South Brazil. Mastozoología Neotropical, 7, 33-36.

Reis, N. R. and Guillaumet, J. L. (1983), Les chauvessoris frugivores de la région de Manaus et leur rôle dans la dissemination des espèces vegetales. Revue d'Ecologie Terre et Vie, 38, 148-169.

Schupp, E. W. (1993), Quantity, quality and the effectiveness of seed dispersal by animals. In: Frugivory and Seed Dispersal: ecological and evolutionary aspects, eds. T. H. Fleming and A. Estrada. Kluwer Academy, Belgium, pp.15-29.

Socolowiski, F and Takaki, M. (2004), Germination of Jacaranda mimosifolia (D. Don - Bignoniaceae) seeds: effects of light, temperature and water stress. Brazilian Archives of Biology and Technology, 47, 785-792.

Statistica for Windows. (1993), Release 4.2 (A). StatSoft, Inc., USA.

Tabanez, A. A. J.; Viana, V. M. and Dias, A. S. (1997), Conseqüências da fragmentação e do efeito de borda sobre a estrutura, diversidade e sustentabilidade de um fragmento de floresta de planalto de Piracicaba, SP. Revista Brasileira de Biologia, 57, 47-60.

Uhl, C.; Clark, K. and Maquirino, P. (1988), Vegetation dynamics in Amazonian treefall gaps. Ecology, 69, 751-763.

Van Der Pijl, L. (1982), Principles of dispersal in higher plants. Springer-Verlag, Berlin.

Vázquez-Yanes, C. and Orozco-Segovia, A. (1986), Dispersal of seeds by animals: effect on light controlled dormancy in Cecropia obtusifolia. In: Frugivores and seed dispersal, eds: A. Estrada and T. H. Fleming. Dr. W. Junk, Dordrecht, pp. 119-134.

Vázquez-Yanes, C.; Rojas-Aréchiga, M.; SánchezCoronado, M. E. and Orozco-Segovia, A. (1996), Comparison of light-regulated seed germination in Ficus spp. and Cecropia obtusifolia: ecological implications. Tree Physiology, 16, 871-875.

Vázquez-Yanes, C. and Orozco-Segovia, A. (1993), Comparative longevity of seeds of five tropical rain forest woody species stored under different moisture conditions. Canadian Journal of Botany, 74, 16351639.

Vieira, E. M. and Izar, P. (1999), Interactions between aroids and arboreal mammals in the Brazilian Atlantic rainforest. Plant Ecology, 145, 75-82.

Received: October 25, 2005; Revised: December 08, 2006; Accepted: April 10, 2007. 